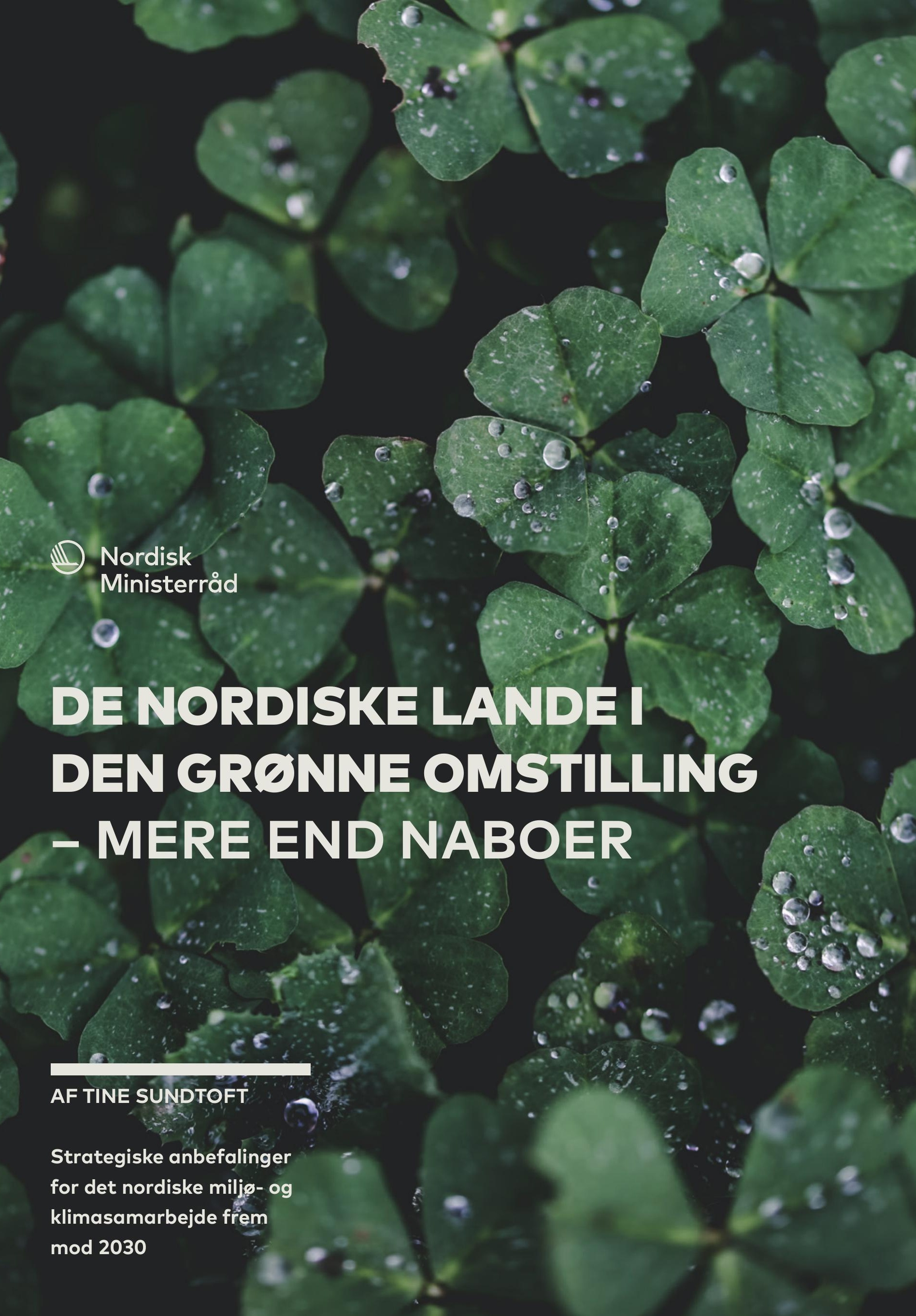




\section{De nordiske lande i den grønne omstilling - mere end naboer}

Strategiske anbefalinger for det nordiske miljø- og klimasamarbejde frem mod 2030

Tine Sundtoft

ANP 2018:749

ISBN 978-92-893-5541-4 (PRINT)

ISBN 978-92-893-5542-1 (PDF)

ISBN 978-92-893-5543-8 (EPUB)

http://dx.doi.org/10.6027/ANP2018-749

(c) Nordisk Ministerråd 2018

Layout: Mette Agger Tang

Omslagsfoto: Scanpix.dk

Tryk: Rosendahls

Printed in Denmark

\section{Det nordiske samarbejde}

Det nordiske samarbejde er en af verdens mest omfattende regionale samarbejdsformer. Samarbejdet omfatter Danmark, Finland, Island, Norge og Sverige samt Færøerne, Grønland og Åland.

Det nordiske samarbejde er både politisk, økonomisk og kulturelt forankret, og er en vigtig medspiller i det europæiske og internationale samarbejde. Det nordiske fællesskab arbejder for et stærkt Norden i et stærkt Europa.

Det nordiske samarbejde ønsker at styrke nordiske og regionale interesser og værdier i en global omverden. Fælles værdier landene imellem er med til at styrke Nordens position som en af verdens mest innovative og konkurrencedygtige regioner.

\section{Nordisk Ministerråd}

Nordens Hus

Ved Stranden 18

1061 København K

www.norden.org

Download nordiske publikationer: www.norden.org/nordpub 


\section{DE NORDISKE LANDE I DEN GRøNNE OMSTILLING - MERE END NABOER}

AF TINE SUNDTOFT

Strategiske anbefalinger

for det nordiske miljø- og

klimasamarbejde frem

$\bmod 2030$

(1) Nordisk

Ministerråd 


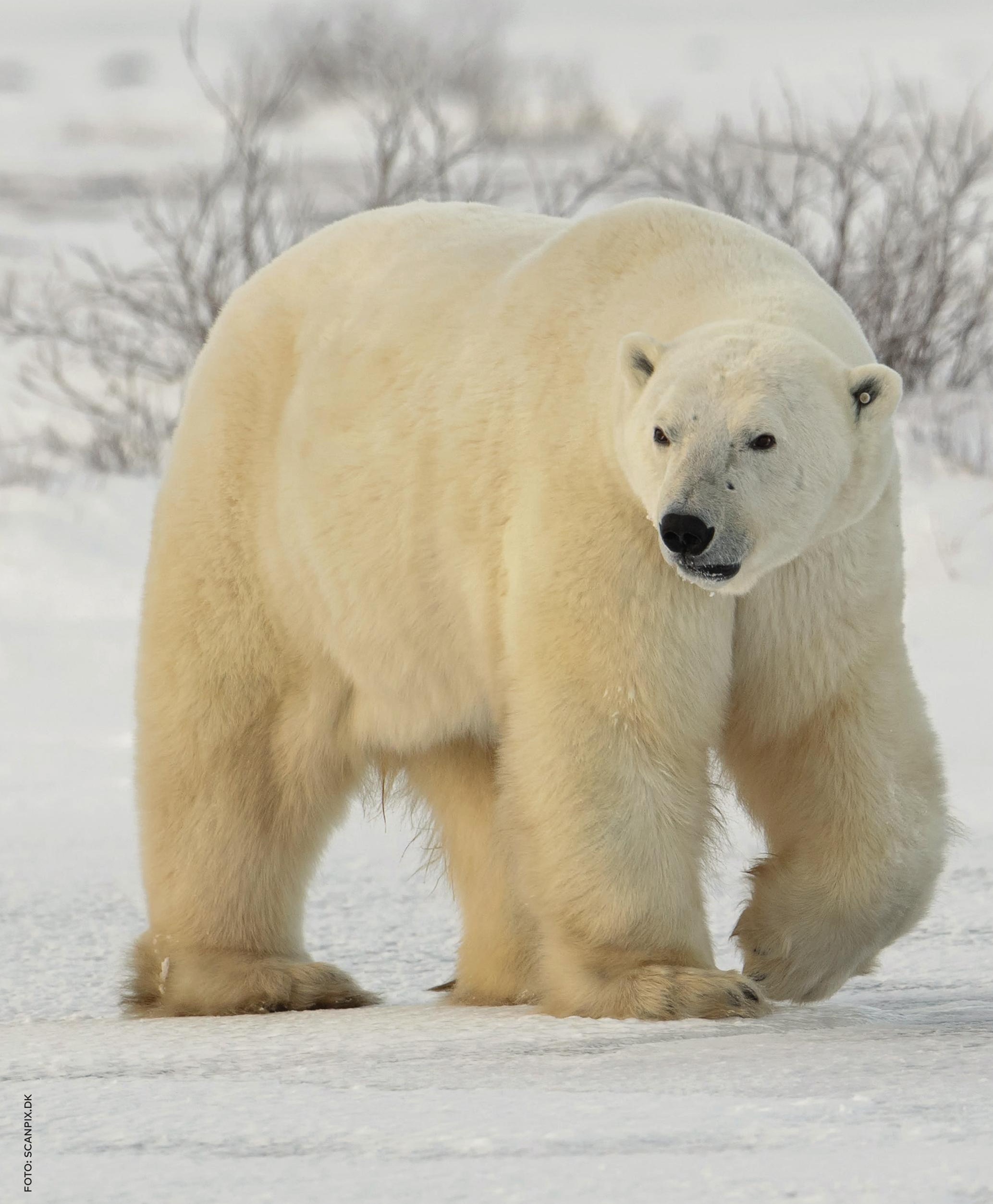




\section{INDHOLD}

7 FORORD

$9 \quad$ INTRODUKTION

12 HOVEDANBEFALING: Bidrage stærkt til opfyldelsen af målene i Parisaftalen og 2030-agendaen i Norden og globalt

14 ANBEFALING 2: Udvikle og implementere en arbejdsplan for det nordiske samarbejde om lavemissionssamfund

16 ANBEFALING 3: Etablere et nordisk forum for en giftfri og cirkulær økonomi for plast

18 ANBEFALING 4: Fremme vidensbaseret substitution af skadelige stoffer gennem EU's kemikalieregulering

20 ANBEFALING 5: Opbygge større kendskab til fordele ved den grønne omstilling

22 ANBEFALING 6: Bidrage til nordisk samarbejde om eksportfremme af nordiske grønne løsninger

24 ANBEFALING 7: Støtte og styrke det nordiske miljømærke Svanen

26 ANBEFALING 8: Støtte landene i at optimere brugen af offentlige midler til fremme af grøn omstilling

28 ANBEFALING 9: Organisere et nordisk topmøde om udvikling af grønne finansmarkeder

30 ANBEFALING 10: Udvikle en plan for nordisk samarbejde i internationale fora

32 ANBEFALING 11: Udarbejde en nordisk handlingsplan for klimaresiliens for okosystemer og naturens mangfoldighed

34 ANBEFALING 12: Videreudvikle former for nordisk samarbejde, som øger nordisk nytte 


\section{FORORD}

I 1950 var der 2,5 milliarder mennesker på kloden. I 2050 vil den samme klode være hjemsted for omkring 10 milliarder mennesker. En firedobling af befolkningen på 100 år. FN har længe sagt, at det ikke kan fungere, uden at vi lægger en plan.

Derfor oprettede de i 1983 Verdenskommission for Miljø og Udvikling (WCED), ofte kaldet Brundtlandkommissionen. Den endelige rapport Our common future pegede på en sammenhæng mellem miljø, økonomi og social udvikling. Vi skal dække det aktuelle behov uden at svække grundlaget for fremtidige generationers mulighed for at dække deres behov.

32 år senere, i 2015, enedes FN's generalforsamling om 17 verdensmål, og senere samme år blev Paris-aftalen vedtaget. Vi skal stræbe efter en temperaturstigning på maksimalt 1,5 grader, alle landene skal opjustere deres mål hvert femte år, og der skal oprettes et robust rapporteringssystem. Alt dette er vigtigt for, at vi kan nå det langsigtede mål om at opnå klimaneutralitet i anden halvdel af dette århundrede.

Både viden og rammeværk er på plads. Nu har Norden chancen for at vise, at der også findes en vilje til at gå forrest i den omstilling, som vi skal igennem for at sikre tålelige leveforhold for de 10 milliarder mennesker, der bor på jorden i 2050.
Jeg har på opdrag af Nordisk Ministerråd rejst rundt i Norden sammen med seniorrådgiver Satu Reijonen. Vi har gået 170 kilometer og cyklet 70 kilometer mellem 119 møder. Vi har mødt forskere, erhvervsledere, politikere, miljøbevægelser, repræsentanter fra kommuner og velgørende organisationer samt mange andre. På alle vores møder har vi diskuteret, om Norden har evnerne og viljen til at vise vej i den omstilling, som verden må og skal gennemgå. Det har vi. Men hvad venter vi så på?

Hvis Norden skal gå forrest, skal de nordiske ledere blive enige om retningen. Mine anbefalinger udstikker en retning for, hvordan Norden kan bidrage globalt, nationalt, regionalt og lokalt. Vi skal trække vores del af læsset, og vi kan også bidrage uden for Norden.

Tak til Nordisk Ministerråd for denne opgave. Tak til alle dem, der velvilligt har stillet deres tid og ekspertise til rådighed på vores møder. Og tak til seniorrådgiver Satu Reijonen for hendes gode selskab og for at have ageret som skribent for rapporten. Indholdet er mit. Jeg tror på, at anbefalingen kan vise vej. En vej, som er nødvendig - i første omgang frem til 2030, men med blikket rettet mod 2050.

\section{5. marts 2018}

Tine Sundtoft 


\section{INTRODUKTION}

De nordiske lande har gennem flere årtier samarbejdet om miljø- og naturbeskyttelse i Norden såvel som internationalt. Det officielle regeringssamarbejde foregår inden for rammerne af Nordisk Ministerråd for Miljø og Klima. I november 2016 besluttede Nordisk Ministerråd for Miljø at bede generalsekretæren iværksætte en ekstern strategisk undersøgelse af det fremtidige potentiale for det nordiske miljø- og klimasamarbejde. Undersøgelsen er en del af reformarbejdet Nyt Norden.

Denne rapport fremlægger anbefalingerne fra dette arbejde. Anbefalingerne udgør undersøgerens uafhængige bidrag til udvikling af det nordiske miljø- og klimasamarbejde. Anbefalingerne fokuserer på arbejdet i den nordiske miljø-og klimasektor i de kommende 5-10 år, men tidshorisonten for dem er længere. Anbefalingerne skal bidrage til opfyldelsen af de miljø-og klimarelaterede verdensmål under FN's 2030-agenda. De beslutninger, som bliver taget i dag, skal også kunne bære udviklingen frem mod den anden halvdel af dette århundrede, hvor de langsigtede mål under Paris-aftalen om klima skal være realiserede.

Undersøgelsesarbejdet er blevet gennemført i løbet af 2017 og de første måneder af 2018. I løbet af denne periode blev der afholdt i alt 119 møder mellem undersøgeren og mere end 200 aktører fra forskellige miljøer i Danmark, Finland, Island, Norge, Sverige, Færøerne, Grønland og Åland. Undersøgeren mødtes også med repræsentanter fra FN/ UNEP og EU. Samtalerne har givet inspiration til og belæg for anbefalingerne.

\section{Overordnede observationer om det nordiske miljø- og klimasamarbejde}

Der findes et stort engagement i det nordiske miljø-og klimasamarbejde, som er velforankret i de nationale ministerier og myndigheder. Det nordiske samarbejde giver indblik, viden og netværk, som deltagerne udtrykker, at de får stor værdi af. De nordiske lande er geografisk, kulturelt og økonomisk tæt tilknyttet hinanden, hvorfor deltagerne kan bruge samarbejdet til gensidig læring og komplementering af hinandens ressourcer og kompetencer.

Uden for de nordiske kredse er det nordiske miljøog klimasamarbejde ikke særligt velkendt. Eksterne interessenter understreger dog det store potentiale i, at de nordiske lande går foran med et godt eksempel og i fællesskab fremmer specifikke miljøog klimaspørgsmål på de internationale arenaer.

Der findes en klar tendens i det nordiske miljø- og klimasamarbejde til at fokusere på vidensproduktion. Det nordiske miljø- og klimasamarbejde har således leveret værdifulde bidrag til viden om forskellige miljø- og klimarelaterede problematikker. Den viden, som produceres i det nordiske samarbejde, er med til at udvikle policyområder og -diskussioner fra en tidlig fase. Mere konkret samarbejde om udvikling og implementering af løsninger prioriteres ikke i samme omfang som vidensproduktion. Sektorens enkeltstående projekter med fokus på konkrete løsninger viser dog potentialet i denne type arbejde.

Det nordiske miljø- og klimasamarbejde beskæftiger sig med spørgsmål af stor relevans for miljø og klima. Samarbejdet spænder over adskillige temaområder fra beskyttelse af vådområder til forretningsmodeller for cirkulær økonomi til gavn for flere forskellige fagmiljøer. Samtidig er paletten af de nordiske aktiviteter forholdsvis fragmenteret, og samarbejdet opererer ikke under klare overordnede strategiske målsætninger og prioriteringer. Tydeli- 
gere prioritering af specifikt udvalgte indsatsområder kunne lede til større synlighed og effekt. Den fremtidige udfordring for sektoren er således, hvordan den kan øge sit strategiske lederskab uden at miste det engagement, som i dag findes i bredden af forskellige temaer og fagmiljøer.

\section{Rapportens struktur og anbefalingerne}

Denne rapport fremlægger 12 anbefalinger til det nordiske miljø- og klimasamarbejde. Intentionen bag anbefalingerne er at pege på muligheder for, hvordan samarbejdet kan udvikle sig som en endnu mere relevant og konkret drivkraft for den grønne omstilling. Opgaven er anseelig. De nordiske samfund skal blive klimaneutrale og giftfrie, samtidig med at ressourceforbruget bliver minimeret. Vi står foran store ændringer i de produktions- og forbrugssystemer, vores samfund er bygget på. Omstillingen til lavemissionssamfund skal for alvor tage fart, for at regionen kan bidrage til Paris-aftalens langsigtede mål. Klimaforandringen, tabet af biodiversitet og skadelige kemikalier i vores hverdag er konkrete udfordringer nu og her.

De 12 anbefalinger knytter sig til fem overordnede områder, hvor det nordiske miljø-og klimasamarbejde bør gøre sig tydeligt gældende. For at opnå størst mulig effekt bør det nordiske miljø- og klimasamarbejde bidrage til:

1. Konkrete løsninger til grøn omstilling

2. Mobilisering af nøgleaktører

3. Finansiering af grøn omstilling

4. En stærk nordisk stemme uden for Nordens grænser

5. Tilpasning til de klimamæssige ændringer.

Den første anbefaling, hovedanbefalingen, beskriver de overordnede rammer, som det nordiske miljø- og klimasamarbejde skal være et stærkt bidrag til. En ambitiøs stræben efter at opfylde målene i Paris-aftalen om klima samt de miljø-og klimarelaterede verdensmål skal være den principielle bevæggrund for det nordiske miljø- og klimasamarbejde.
Konkrete løsninger til grøn omstilling. Anbefalingerne 2-4 præsenterer tre forslag til indsatser og indsatsområder til udvikling af konkrete tiltag og løsninger. Den første anbefaling foreslår, at det nordiske samarbejde anlægger en strategisk tilgang til arbejdet hen imod et lavemissionssamfund. Der bør udvikles en langsigtet, tematisk arbejdsplan for nordisk samarbejde for lavemissionssamfund. Arbejdsplanen skal udmøntes i konkrete indsatser og handlinger inden for udvalgte indsatsområder. Anbefaling 3 løfter cirkulær økonomi op som et centralt samarbejdsområde og foreslår et særligt spydspidsinitiativ angående cirkulær økonomi og plast. Dette arbejde bygger på det igangværende nordiske arbejde og spiller sammen med udviklingen i EU. Erfaringerne fra plastområdet kan overføres til andre materialestrømme, hvor cirkulariteten bør øges. For det tredje anbefales, at det langsigtede arbejde hen imod substitution af skadelige kemikalier bliver et prioriteret indsatsområde. Udviklingen af EU's kemikalieregulering og dens implementering er en forudsætning for, at skadelige kemikalier systematisk og risikofrit kan substitueres i fremtiden. Derfor anbefales en fortsat og øget nordisk indsats på området.

Mobilisering af nøgleaktører. Beslutninger om implementering af lavemissionsløsninger og ændringer på systemniveau tages oftest uden for miljø- og klimasektoren. Det er vigtigt, at alle relevante aktører bliver engageret og opererer med aktuel viden om fordele ved forandringen. Anbefaling 5 opfordrer den nordiske miljø- og klimasektor til at spille en faciliterende og katalyserende rolle gennem vidensdeling om de økonomiske og sociale fordele ved grøn omstilling. Anbefaling 6 foreslår, at miljø- og klimasektoren skal bidrage til nordisk samarbejde om eksport af nordiske grønne løsninger. Anbefaling 7 gør arbejdet med miljømærket Svanen til et prioritetsområde inden for sektorens arbejde direkte rettet mod forbrugerne. 
Finansiering af grøn omstilling. En grundlæggende omstilling til renere og klimaneutrale produktionsog forbrugssystemer kræver store investeringer $i$ grønne teknologier, infrastruktur og forvaltningsmæssige innovationer. Der er brug for en betydelig mobilisering af både offentlig og privat kapital. Anbefaling 8 foreslår nordisk erfaringsudveksling om offentlige støttemekanismer for grønne innovationer, grønt offentligt indkøb og offentlige infrastrukturinvesteringer i grønne innovationer. Anbefaling 9 understreger behovet for at initiere nordiske drøftelser på politisk topniveau om udvikling af et grønt finansmarked.

En stærk nordisk stemme uden for Nordens grænser. Anbefaling 10 adresserer muligheden for at styrke den nordiske indflydelse gennem fremadrettet planlægning af de nordiske indsatser i de vigtigste internationale forhandlingsprocesser.

Tilpasning til de klimamæssige ændringer. Stigende temperaturer og havniveau kommer til at øge presset på vores allerede udfordrede økosystemer og biodiversitet. Dermed risikerer vi, at grundvilkårene for produktionen af mad samt tilgang til rent vand og luft svækkes. Anbefaling 11 understreger betydningen af samarbejde omkring økosystemresiliens over for klimamæssige ændringer i regionen.

Den sidste anbefaling i denne rapport omhandler metoder til organisatorisk at fremme effektiviteten og engagementet i det nordiske miljø- og klimasamarbejde. 


\title{
HOVEDANBEFALING
}

\author{
BIDRAGE STAERKT TIL OPFYLDELSEN AF MÅLENE \\ I PARIS-AFTALEN OG 2030-AGENDAEN I NORDEN OG \\ GLOBALT
}

Verden står samlet omkring Paris-aftalen om klima og 2030-agendaen. Det nordiske miljø- og klimasamarbejde bør bruges som et strategisk værktøj til at fremme og implementere disse aftaler både på nationalt og internationalt niveau.

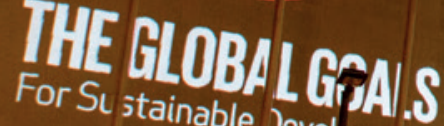 \\ tainable Jevel spm ant}

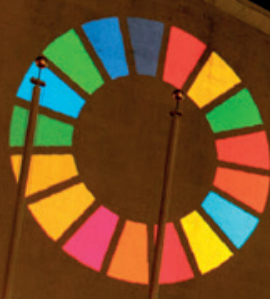


Mere end nogensinde før hersker der enighed mellem verdens lande om de største miljø-og klimamæssige udfordringer. FN's medlemslande er blevet enige om FN's verdensmål for bæredygtighed. Paris-aftalen om klima udstikker en retning for landenes arbejde med at begrænse klimaforandringer. Denne fælles forståelse for og bestræbelse på at løse verdens mest brændende miljøproblemer kommer på et tidspunkt, hvor naturens tålegrænse for alvor er truet.

I deres artikel fra 2017 understreger den tidligere FN-klimachef Christiana Figueres og Hans Joachim Schellnhuber fra Intergovernmental Panel on Climate Change m.fl., at hvis det lykkes os at nedbringe klimaudslip i tilstrækkeligt omfang inden 2020, kan vigenkaldelige ændringer i klimaet stadig undgås. Men tiden er ved at rinde ud for muligheder for at holde den globale opvarmning under to grader, som stipuleret i Paris-aftalen om klima. Jo længere vi venter, desto sværere og dyrere bliver arbejdet mod forandringerne i klima og natur. Konsekvensen kan være, at meget af det arbejde, som landene har ydet i forbindelse med andre miljøudfordringer, såsom arbejdet mod tabet af biodiversitet, bliver spildt. Udvikling og implementering af Paris-aftalen skal derfor stå øverst på dagsordenen i det nordiske miljø- og klimasamarbejde i den nærmeste fremtid.

Uanset hvor meget vi når at nedbringe $\mathrm{CO}_{2}$-emissioner, er klimaforandringer allerede en realitet. Dette gælder hele Norden, især Arktis, hvor kontinuerlig opvarmning er særligt tydelig. Det kræver, at vi også minimerer de relaterede skader, bl.a. på biodiversiteten, som nye vejrforhold måtte forårsage. Det betyder, at arbejdet med klimaet også omfatter arbejde med klimatilpasning.

Videnskaben advarer os også om en endnu større udslettelse af biologisk mangfoldighed som følge af menneskelige aktiviteter. Nedgangen i naturens mangfoldighed er således en af de største udfordringer for den nordiske natur i dag. De kommende år vil vise, hvorvidt vi kan bremse tabet af naturens mangfoldighed i regionen, både på jorden og i havet. Bevarelsen og beskyttelsen af den biologiske mangfoldighed sikrer, at de tjenester, som naturen yder os for eksempel i form af mad, vand, luft, materialer og medicin, også findes i fremtiden. Desuden spiller biodiversiteten en afgørende rolle i at bevare robustheden og modstandskraften i vores økosystemer over for de udfordringer, som klimaforandringerne giver.

En tredje stor miljøudfordring er menneskets og naturens stigende eksponering for skadelige kemikalier fra produkter og produktionsprocesser. Undersøgelser viser et øget antal forskellige skadelige kemikalier i blodet og kropsvævet hos mennesker, inklusive pesticider, biocider, tungmetaller, blødgørere og brandhæmmende kemikalier. Skadelige kemikalier spreder sig overalt: Kemikalier, som bruges og produceres andre steder $\mathrm{i}$ verden, bliver $\mathrm{fx}$ fundet $\mathrm{i}$ de sårbare arktiske områder. Vi kender ikke de fulde samfundsøkonomiske og sundhedsmæssige konsekvenser af menneskets, miljøets og naturens eksponering for de kræftfremkaldende, hormonforstyrrende, neurotoksiske eller på andre måder skadelige kemikalier.

Paris-aftalen om klima og de 17 verdensmål baserer sig på viden om adskillige negative udviklinger i vores klima og natur. Det mest grundlæggende ved disse to aftaler er dog ikke budskabet om bekymring, men om viljen til forandring. Gennem disse aftaler har verden samlet sig omkring omstillingen.

Det er afgørende, at verden bibeholder sit engagement i implementeringen af Paris-aftalen og 2030-agendaen. De nordiske landes miljøsamarbejde skal tage udgangspunkt i at drive den krævede omstilling i vores egen region, men også i at støtte den i andre regioner. Vi skal bruge Paris-aftalen og de 17 verdensmål som ledetråd for at omlægge vores forbrugs- og produktionsmønstre, som i dag bidrager til klimaforandringer, ikke-bæredygtigt materialeforbrug, tabet af biodiversitet og den stigende kemikalisering af vores dagligdag. Hovedmålet for det nordiske miljø- og klimasamarbejde skal være at bidrage stærkt til implementeringen af Paris-aftalen og 2030-agendaen både i Norden og globalt. 


\section{ANBEFALING 2 \\ UDVIKLE OG IMPLEMENTERE EN ARBEJDSPLAN \\ FOR DET NORDISKE SAMARBEJDE OM \\ LAVEMISSIONSSAMFUND}

De nordiske lande har forpligtet sig til reduktioner af klimaemissioner i både EU og FN.

Derudover deler alle nordiske lande ambitionen om at blive klimaneutrale. Den nordiske miljøog klimasektor bør anlægge en mere systematisk tilgang til arbejdet for klimaneutralitet ved at etablere og følge en tematiseret arbejdsplan for det nordiske samarbejde om lavemissionssamfund.

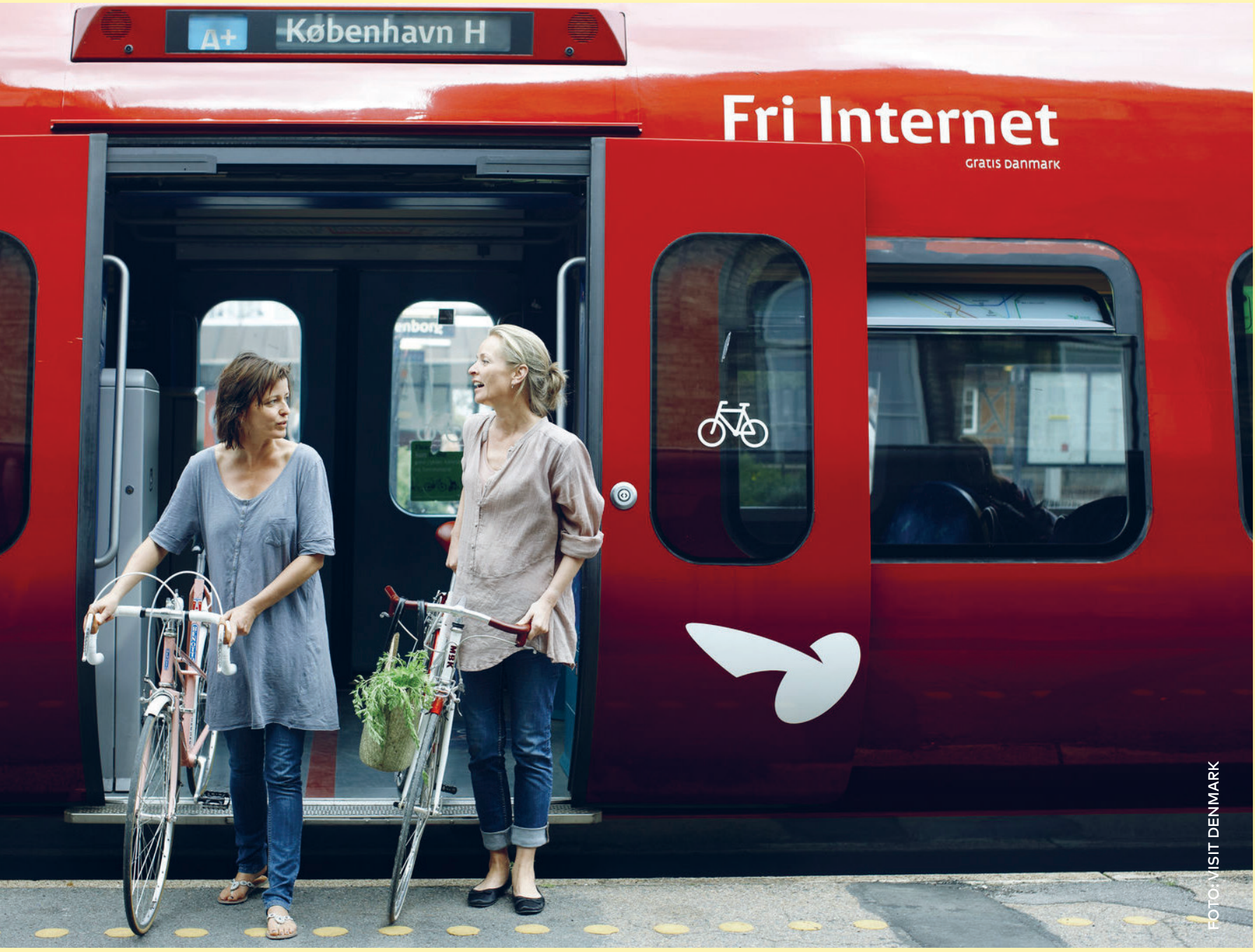


De nordiske lande står for at opfylde EU's klimareduktionsmålsætninger for 2030 og de langsigtede målsætninger i forlængelse af Paris-aftalen om klima. Der er fortsat behov for betragtelige $\mathrm{CO}_{2}$-reduktioner i alle de nordiske lande og især inden for sektorer, som endnu ikke har formået at stabilisere deres klima- udslip. Der er fortsat lang vej, før Norden kan kaldes en klimaneutral region, især hvis man også medregner emissioner relateret til vores forbrug udledt uden for Norden.

Omstillingen, som de nordiske lande skal igennem, er noget, vi kan og bør være fælles om. Mange af de udfordringer, de nordiske lande står overfor, ligner hinanden fra land til land. Fra et globalt perspektiv er vores livsstil, byer, boliger og transportmekanismer ligeledes ens. Samlet set er Norden desuden i besiddelse af en række komplementerende teknologiske og planlægningsmæssige løsninger og kompetencer, som kan bringe os tættere på målet. Ydermere udgør de nordiske lande verdens 11. største økonomi med en stor grøn købekraft og dermed store forandringsressourcer.

For at opfylde vores klimamålsætninger må vi rette blikket mod arbejdet, som giver konkrete resultater. Det nordiske klimasamarbejde skal derfor fokusere på konkrete bidrag til omstillingen til lavemissionssamfund. Vi har brug for at implementere de lovende klimainnovationer, som allerede har vist deres effekt. Ydermere skal vi sætte fart på ændringer på systemniveau inden for energi, byggeri, mad og transport. Løsninger inden for disse områder er også nøglen til en konkurrencedygtig region og et stærkt erhvervsliv i den fremtidige klimaneutrale verden.

Konkret er anbefalingen, at den nordiske miljøog klimasektor udvikler og implementerer en arbejdsplan for nordisk samarbejde om lavemissionssamfund i 2050 eller tidligere. Arbejdsplanen skal fremme klimalederskab, erfaringsudveksling, dialog og dybere nordisk samarbejde på strategisk udvalgte områder. Den skal bringe det nordiske samarbejde tættere på de konkrete valg og beslutninger, som landene hver for sig tager og gennem- fører for at blive klimaneutrale. Hovedelementerne i arbejdsplanen vil være:

1. Skemalagte drøftelser af nøgletemaer inden for klimaneutralitet, såsom lavemissionsmobilitet, byggeri og bolig, klimaneutrale byer og småsamfund, mad, energi, trade-offs mellem klima og biodiversitet og udvikling af klimalovgivning

2. Nordisk erfaringsudveksling som en del af drøftelserne af hvert nøgletema, fx angående omkostningseffektive indsatser, virkemidler med eventuel negativ klimaeffekt og finansieringsmekanismer til implementering af grønne innovationer

3. Konkretisering af det videre nordiske samarbejde om temaerne, fx koordineret vidensproduktion til brug i policyprocesser eller internationale forhandlinger, fælles spilleregler eller harmonisering af regler, nordisk arbejdsdeling og samarbejde med erhvervsliv.

Skemalagte drøftelser understøttes af baggrundsmateriale, som fremstilles specifikt for hvert tema.

Temaerne drøftes på nordisk plan, gerne af ministrene. I og med at beslutninger om løsninger og virkemidler til etablering af lavemissionssamfund ofte tages af andre end miljø- og klimaaktører, bør drøftelserne gennemføres i dialog med andre fagministre og relevante aktører. For eksempel spiller aktørerne inden for transport-, energi-, byggeri- og byudviklingsområdet nøgleroller i implementeringen af Paris-aftalen. Her kan miljø-og klimasektoren vise lederskab ved at påtage sig en initierende og katalyserende rolle med sit vidtgående kendskab til klima- og miljøeffekter og sin viden om virkemidler og løsninger til grøn omstilling. 


\section{ANBEFALING 3 \\ ETABLERE ET NORDISK FORUM FOR EN GIFTFRI OG CIRKULAER ØKONOMI FOR PLAST}

For at minimere de negative effekter på vores natur, vandmiljø og klima forårsaget af brug af plast bør de nordiske lande systematisk samarbejde for at skabe en plastøkonomi, som er baseret på produkter med lang levetid, design for genanvendelse, giftfrit kredsløb og velfungerende markeder for genanvendt plast. Der bør etableres et nordisk forum for at fremme dialog, erfaringsudveksling og koordinering af de nationale indsatser for en giftfri og cirkulær økonomi for plast. Forummet kan også initiere nordiske projekter på området.

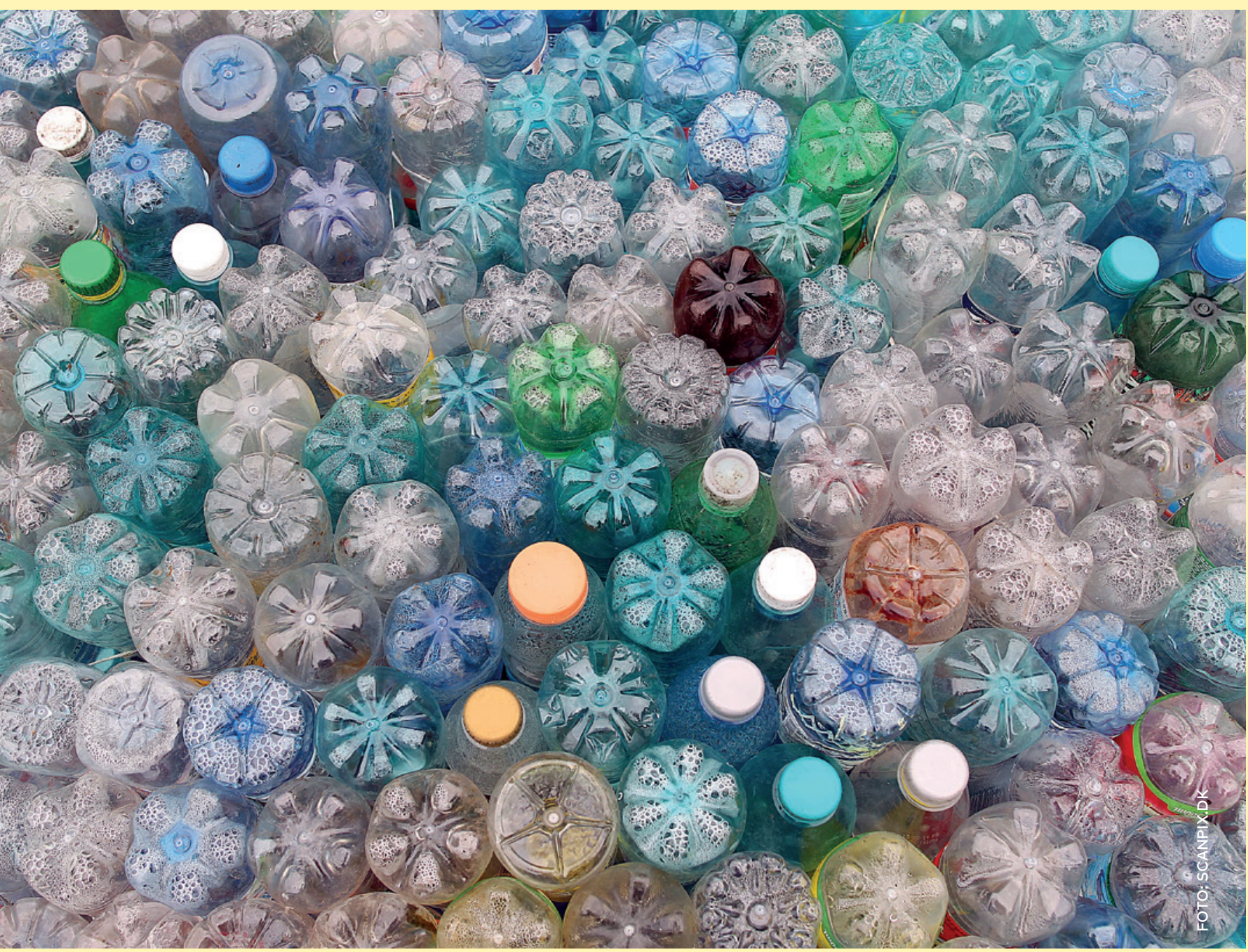


De nordiske økonomier bør i fremtiden baseres på et cirkulært snarere end et lineært forbrug af ressourcer. Dette gælder i sidste ende al produktion og forbrug, dog står nogle materialer højere på agendaen end andre i startfasen af dette arbejde. Plast er et af de materialer, hvor arbejdet må prioriteres. Plastforbruget i Norden såvel som andre steder i verden er stort og stadigt voksende. De relaterede miljø- og klimamæssige problemer er nået til et punkt, hvor vi ikke har noget andet alternativ end at bringe cirkulariteten ind i plastanvendelsen.

På nordisk plan har man i en årrække arbejdet med plastagendaen, senest under det igangværende program Nordisk program for at reducere miljøpåvirkningen af plast 2017-18. De nordiske lande arbejder også aktivt med plast og miljø på nationalt plan. Der mangler dog stadigvæk en del, før plastproduktionen og -forbruget i Norden kan kaldes bæredygtig: Hvert år ender 700.000 ton plast i forbrænding eller i deponier i Norden. Samtidig er genanvendelsesgraden af plast relativt lav i sammenligning med andre materialer. Der findes et stort uudnyttet potentiale i genbrug og genanvendelse af plast i samtlige nordiske lande.

I kraft af tidligere arbejde inden for plastområdet er der stor enighed omkring de største barrierer for en cirkulær økonomi for plast. Trods dette mangler vi stadigvæk at forstå præcist, hvordan disse problemer kan løses. Manglende design for lang levetid og genanvendelse, manglende transparens i værdikæden angående materialer og tilsætningsstoffer, herunder skadelige kemikalier, manglende indsamlings-og sorteringskapacitet og prisen på sekundært plastmateriale er nogle af de problemer, som skal løses.

De nordiske lande bør anvende det nordiske samarbejde til at nærme sig løsninger på de ovennævnte problemer. Alle de nordiske lande er allerede godt i gang med deres nationale arbejde med plast. Derfor bør øget koordinering mellem landene angående både national vidensproduktion og erfaringsudveksling relateret til konkrete tiltag være hovedelementer i samarbejdet. På denne baggrund anbefales det, at der i regi af det nordiske miljø- og klimasamarbejde etableres et dialog-og koordineringsforum for landenes indsatser og nordisk samarbejde for en cirkulær og giftfri økonomi for plast. Udover facilitering af koordination og erfaringsudveksling skal nordiske midler bruges til at udarbejde opdateret information om landenes og andre vigtige aktørers aktiviteter. Ydermere kan der etableres særlige fællesnordiske initiativer for eksempel i form af fælles forskningsprojekter, pilotog demonstrationsprojekter, kapacitetsopbygning, udvikling af finansieringsinstrumenter eller kommunikation med nøgleaktører. Gennem forummet kan Norden også give et stærkt bidrag til udviklingen af plastpolitik i Europa og til implementeringen af EU-strategien for plast i den cirkulære økonomi.

Erfaringerne fra det foreslåede plastarbejde kan overføres til nordisk samarbejde om andre materialestrømme, hvor cirkulariteten bør øges. 


\section{ANBEFALING 4 \\ FREMME VIDENSBASERET SUBSTITUTION AF SKADE- LIGE STOFFER GENNEM EU'S KEMIKALIEREGULERING}

Den langsigtede nordiske målsætning på kemikalieområdet bør være, at skadelige stoffer i produkter og produktion erstattes med mindre problematiske alternativer. For at substitution kan ske på en sikker og velinformeret måde, bør en stærk og velimplementeret EU-kemikalielovgivning fortsat prioriteres højt i det nordiske miljøsamarbejde. De nordiske lande bør fortsat samarbejde for at udvikle værktøjer og viden til evalvering af effekter af kemikalier med henblik på substitution af problematiske stoffer.

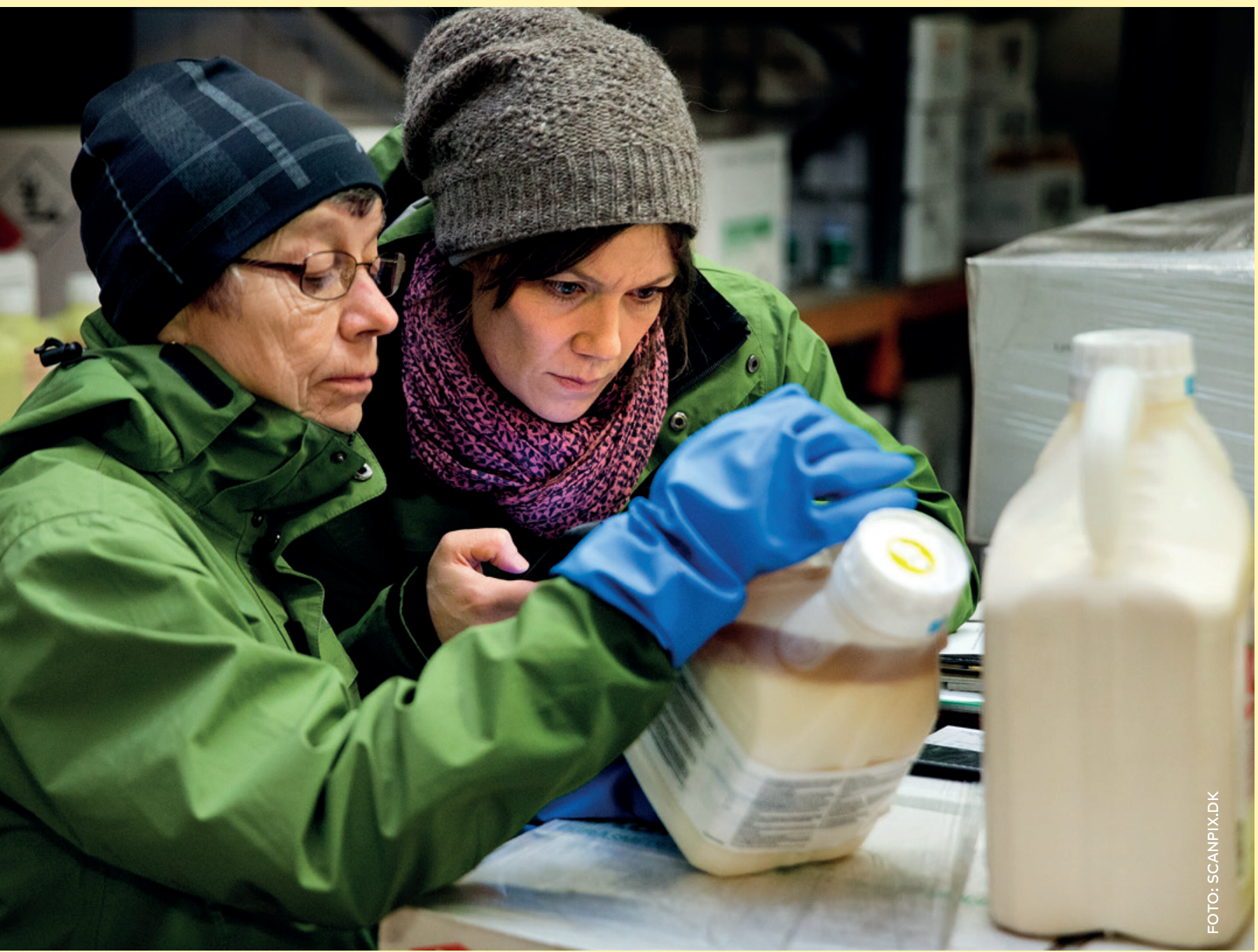


Det langsigtede mål for det nordiske miljøsamarbejde om kemikalier bør være en effektiv og miljømæssigt bæredygtig substitution af skadelige kemikalier der, hvor deres anvendelse skaber risiko for miljøet og mennesket. Substitution skal bygge på viden om effekterne af de skadelige stoffer og af de erstattende kemikalier. Først når vi kender effekterne af kemikalier, kan de eventuelle politiske beslutninger om restriktioner eller substitution af stoffer tages. Omstillingen til en cirkulær økonomi gør erstatningen af skadelige kemikalier endnu vigtigere. For at muliggøre et giftfrit kredsløb skal problematiske stoffer erstattes i de materialer, som genanvendes.

En vidensbaseret tilgang til effekter af kemikalier samt deres anvendelse og håndtering ligger til grund for EU/EØS's kemikalieregulering. I implementering af både REACH og CLP skal en eventuel regulering af anvendelsen af kemikalier være baseret på en vurdering af stoffernes skadelige effekter. Der findes over 100.000 kemikalier på markedet i dag. Mange af disse stoffer mangler vi grundlæggende viden om.

De nordiske lande har stor interesse i, at EU's kemikalieregulering og -forvaltning bliver så robust som muligt. Fordelen ved et system på EU/EØS-niveau er, at det leder til miljøforbedringer over landegrænser. Ydermere skaber dette en "level playing field" og minimerer grænsehindringer for virksomheder. Dette muliggør en strammere kemikalielovgivning uden negative konsekvenser for landenes konkurrenceevne.

Særligt problematiske stoffer (SVHC-stoffer) og strategier for deres erstatning med mindre farlige stoffer eller alternative teknikker er et af arbejdsområderne, hvor det nordiske miljøsamarbejde giver tydelig merværdi. Nordisk input har været og kommer til at være vigtigt i fastlæggelsen af de kriterier, som anvendes i defineringen af særligt problematiske stoffer, i screeningen af disse, $i$ vurderingen af stoffernes effekter og $i$ etableringen af risikominimerings- og reguleringsstrategier for disse stoffer. Der er også behov for nordiske bidrag til at effektivisere REACH's arbejde, bl.a. med udviklingen af den såkaldte gruppebedømmelsesmetodik.

Succesfuldt screenings- og vurderingsarbejde kræver udvikling af testmetoder. Testmetodeudvikling påvirker, hvilke effekter det er muligt at inkludere i vurderingen af kemikaliers skadelighed. Nordisk deltagelse i testmetodeudviklingen er derfor fortsat en omkostningseffektiv måde at sikre, at der i vurderingen af stoffer og i sidste ende håndteringen af disse kan tages højde for spørgsmål af nordisk interesse, såsom hormonforstyrrende effekter, nanomaterialer og eventuelt også stoffer, som importeres eller produceres i lav volumen. På kemikalieområdet har dette videnstunge prepipeline-arbejde derfor stor politisk vægt. En vigtig samarbejdspartner er OECD med sit Test Guidelines Programme.

På de områder, hvor vidensbasen for erstatning af skadelige kemikalier er tilstrækkeligt stærk, er det aktuelt at rette blikket mod, hvordan substitution af skadelige stoffer kan fremmes i virksomheder. De nordiske lande skal aktivt undersøge mulighederne for ressourceeffektiv organisering af informationsformidling angående substitution enten $i$ det nordiske regi eller i relation til EU, eksempelvis gennem EU's Kemikalieagentur ECHA. 
Beslutninger, som driver grøn omstilling og god natur- og miljøstatus, bliver ofte taget uden for den nordiske miljø- og klimasektor. Selvom miljøbevidstheden er stigende, er der fortsat behov for øget opmærksomhed omkring fordelene ved grøn omstilling for økonomi og samfund. Jo tydeligere dette gøres, desto større kan vi forvente, at engagementet bliver hos andre relevante aktører.

Den nordiske miljø- og klimasektor har allerede påbegyndt arbejdet med at synliggøre sammenkoblinger mellem miljøspørgsmål, økonomi og samfund. Arbejdet med økosystemtjenester, alternativer til BNP og økonomiske beregninger af effekter af visse kemikalier på den reproduktive sundhed er gode eksempler herpå. For at få andre sektorer og aktører på banen bør den nordiske miljø- og klimasektor systematisk inddrage samfundsøkonomiske beregninger, $f x$ relateret til fordele ved nedsat brug af olie eller andre klima- og miljømæssigt problematiske råvarer, sårbare landarealer og økosystemer eller skadelige kemikalier. Samfundsøkonomiske analyser om fordele ved specifikke tiltag er især interessante i sammenligning med vurderinger af prisen på disse tiltag samt omkostningerne ved ikke at gøre noget.

Samfundsøkonomiske konsekvenser er vigtige, men ikke altid de eneste, som skaber opbakning bag og legitimitet for grøn omstilling. Tal, der viser, hvor mange arbejdspladser der ligger i cirkulær økonomi, eller tal, der viser, hvor mange mennesker som ikke har mulighed for at blive forældre på grund af brug af hormonforstyrrende stoffer, kan være lige så virkningsfulde. Et interaktivt kort over fremtidens klimarelaterede konflikter og flygtningestrømme kan være illustrativt for de sociale og politiske udfordringer, som klimaændringen kan medføre. På den anden side af spektret skal vi også kommunikere budskabet om et godt, klimaneutralt liv.

Udover at synliggøre fordelene for samfundsøkonomien og individet skal de konkurrencemæssige fordele ved den grønne omstilling kommunikeres. Vi har brug for en business case for grøn omstilling for at engagere erhvervslivet, politikere og myndigheder med ansvar for nøglepolitikområder. 


\section{ANBEFALING 6 BIDRAGE TIL NORDISK SAMARBEJDE OM EKSPORT- FREMME AF NORDISKE GRØNNE LØSNINGER}

Samlet set besidder de nordiske lande mange af de teknologier og andre løsninger, som verden har brug for for at kunne omstille sig. Vi har højtudviklede løsninger på områder såsom vand, affald, grøn byudvikling, transport og energi. Ofte er de kompetencer og løsninger, som de enkelte nordiske lande besidder individuelt, kompletterende for hinanden. Det nordisk miljøog klimasamarbejde bør bidrage til at fremme det spirende nordiske samarbejde om eksport af grønne løsninger. 
Ifølge rapporten State of the Nordic Region 2018 er Norden den mest innovative region i Europa, ikke mindst hvad angår rene teknologier. Samlet set besidder de nordiske lande allerede mange af de løsninger, som er nødvendige for opfyldelsen af Paris-aftalen om klima og de miljø- og klimarelaterede verdensmål. Norden har højtudviklede løsninger på områder såsom vand, affald, grøn byudvikling, transport og energi. Ved hjælp af nordisk samarbejde kunne disse løsninger blive omsat til endnu større værdiskabelse på globale markeder.

De globale markeder for bæredygtige teknologier og andre løsninger vokser hurtigt, og der er plads til produkter og servicer fra alle nordiske lande. Problemet lader til nærmest at være omvendt: Allerede nu oplever de nordiske virksomheder, at de nationale erhvervsklynger er for små til at høste globale markedspotentialer. På mange områder er de kompetencer og løsninger, som de enkelte nordiske lande besidder individuelt, desuden komplementerende for hinanden. Dette giver os mulighed for at tænke i samarbejde i stedet for konkurrence, når vi opererer på de globale markeder. Norden har enormt potentiale til at indgå i partnerskab i forhold til markedsskabelse for grønne løsninger på verdens store markeder såsom Kina, Indien og Nordamerika.

De først skridt til at støtte fælles værdiskabelse gennem nordisk samarbejde om eksport af grønne løsninger er lige blevet taget. Hovedformålet for det nordiske statsministerinitiativ Nordiske løsninger på globale udfordringer fra 2017 er at fremme nordisk branding af løsninger fra nordiske virksomheder. Et af arbejdsområderne under statsministerinitiativet er nordiske løsninger for bæredygtige byer. Udover nordisk branding inden for temaet Nordic Sustainable Cities støttes også konsortiedannelse for nordiske virksomheder samt matchmaking mellem konsortier og potentielle internationale indkøbere. Disse aktiviteter styres af Nordic Innovation (NI), en nordisk institution under Nordisk Ministerråd for Bæredygtig Vækst, i tæt kontakt med de nationale eksportråd og ambassaderne.
Projektet Nordic Energy Solutions vil desuden præsentere nordiske energiløsninger og -virksomheder med fokus på elmarkeder i Østafrika under ledelse af Nordisk Energiforskning (NEF).

Kapitalisering på landenes nationale satsninger inden for grønne løsninger kan have erhvervsfremmende effekter og skabe resultater på bundlinjen. Dette øger legitimiteten af en ambitiøs miljø- og klimapolitik i landene. Det er derfor i de nordiske miljø- og klimaministres interesse at bidrage til at udvikle det spirende grønne eksportsamarbejde. Derfor anbefales det, at miljø- og klimaministrene følger op på erfaringerne fra eksportsamarbejdet i dialog med erhvervsministrene. Baseret på erfaringerne fra de igangværende og planlagte aktiviteter kan sektorerne undersøge behov for yderligere nordiske aktiviteter inden for temaet bæredygtige byer. Disse kan eventuelt relatere sig til udvikling af en specifik eksportklynge, såsom vandforsyningsteknologier og -systemer, affaldsteknologier eller nye tiltagstyper.

Den nordiske miljø- og klimasektor bør også bidrage til identifikation af andre potentielle områder inden for grønt eksportsamarbejde. Disse kunne efterfølgende blive genstand for en lignende nordisk indsats vedrørende branding og opbyggelse af eksportklynger i forlængelse af statsministerinitiativet eller i en anden kontekst. Nordiske eksportstyrker kunne eventuelt findes i områder såsom bæredygtig naturforvaltning, klimatilpasning eller cirkulær økonomi. Nordisk projekteksportfond (Nopef) og de nationale eksportkreditorganisationer kan også være vigtige spillere i samarbejdet om eksport af nordiske grønne løsninger. 


\section{ANBEFALING 7 \\ STØTTE OG STYRKE DET NORDISKE \\ MILJØMAERKE SVANEN}

Det nordiske miljømærke Svanen er den bedste måde, hvorpå det nordiske miljø- og klimasamarbejde kan nå direkte ud til forbrugeren. Ved at købe produkter med Svanemærket får forbrugeren større indflydelse på miljøeffekterne af sit forbrug. Derfor bør det nordiske miljøsamarbejde fortsat støtte og styrke Svanemærket. Dette kan ske på flere forskellige måder. Udover sektorens direkte bidrag til den nordiske Svanemærkeorganisation kan også arbejdet med offentlige indkøb og arbejdet for positive prisincitamenter for miljømærkede produkter være en frugtbar måde at styrke Svanen på.

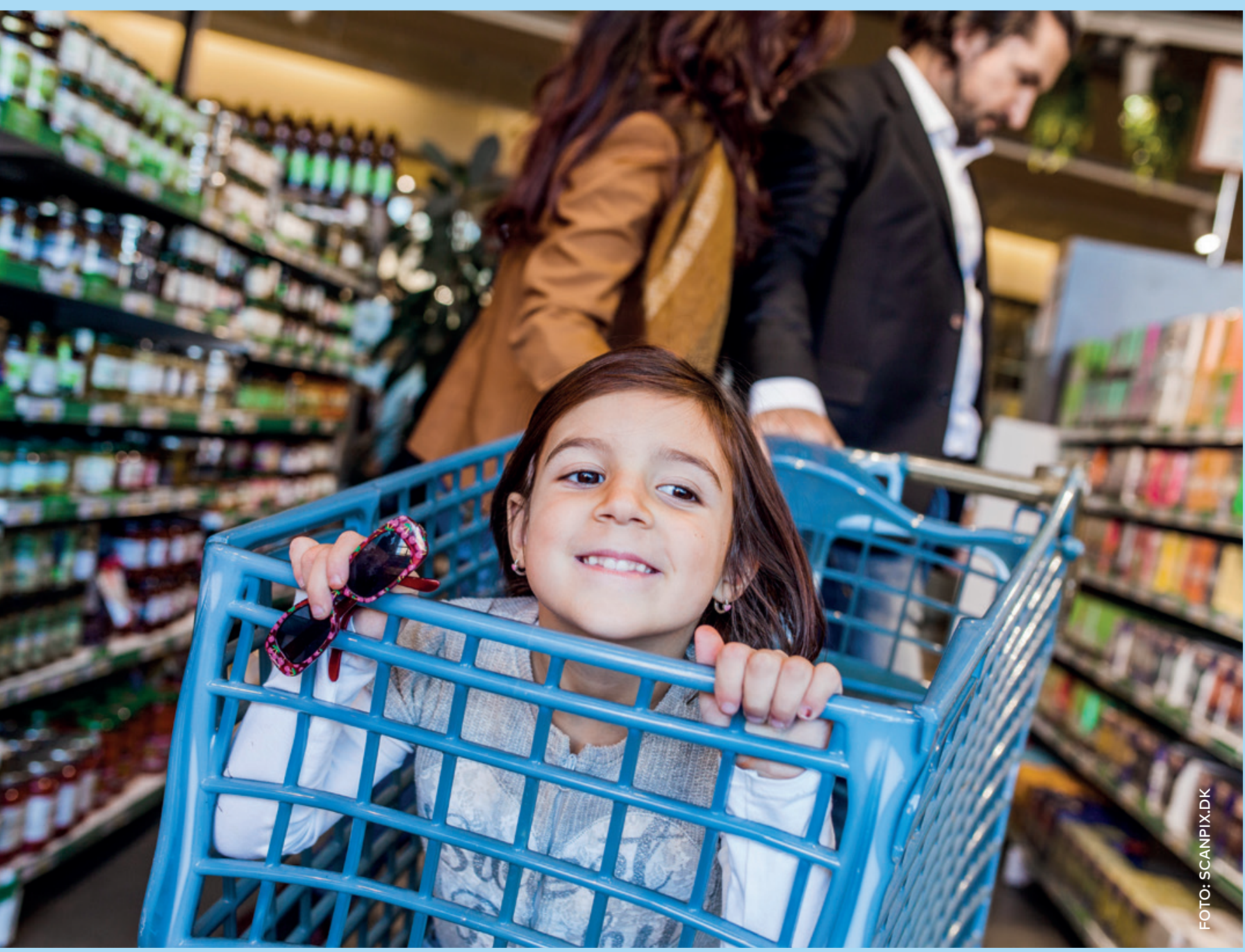


Svanemærket, det officielle nordiske miljømærke, blev stiftet i 1989 af Nordisk Ministerråd. Det er det bedst kendte miljømærke i Norden, hvor hele 89 procent af befolkningen genkender logoet. Svanen er et vigtigt redskab til at styrke og stimulere forbrugerkompetencer: Det muliggør et troværdigt og miljøbevidst valg uden ekspertviden.

Det nordiske miljø- og klimasamarbejde bør fortsat spille en aktiv rolle i at støtte og styrke Svanemærket, så dets rolle bliver endnu stærkere, hvad angår stimulering af bæredygtigt forbrug. Dette kan gøres på mange måder og på mange forskellige planer. Før det første bør den nordiske miljø- og klimasektor fortsat støtte og samarbejde med den nordiske Svanemærkeorganisation om strategisk udvikling af Svanen. Flere skal købe svanemærkede produkter, flere svanemærkede produkter skal findes på markederne, og der skal findes flere produktgrupper, hvori svanemærkede produkter indgår. Ydermere er en gennemgribende digitalisering af Svanen nødvendig for at ruste Svanen til en digital verden.

For det andet kan det nordiske miljø- og klimasamarbejde styrke Svanen ved at fremme miljømærker i regi af offentligt indkøb. I 2017 publiceredes nordiske retningslinjer for fortolkning af EU's nye direktiv om offentligt udbud fra 2014 specifikt angående brugen af miljømærker i EU-udbud. Sammen med flere andre nordiske projekter om grønt indkøb giver disse retningslinjer en god basis for videre arbejde for at fremme brugen af miljømærker, herunder Svanen, i offentlige indkøb.

En tredje måde, det nordiske miljø- og klimasamarbejde kan bidrage til Svanemærket på, er ved at undersøge mulighederne for at opbygge et positivt prisincitament for miljømærkede produkter. Miljørigtigt forbrug bør være nemt, enkelt og økonomisk lønsomt, for at man for alvor kan høste effekten af forbrugernes vilje til at omstille sig. Trods dette er det i dag licensindehaveren, og i sidste ende køberen, som betaler omkostningerne relateret til miljømærkningen af produktet.
Nordisk Ministerråd har intet decideret ministerråd eller nogen arbejdsgruppe for forbrugerspørgsmål, og forbrugermyndighederne deltager - med få undtagelser - ikke i det nordiske miljø- og klimasamarbejde. I denne situation skal miljø- og klimasektoren prioritere anvendelsen af sine midler, når det gælder at nå direkte ud til forbrugerne. Fra ministerrådets perspektiv må miljømærkningen Svanen være den mest effektive og velfungerende måde at opnå resultater på dette område. Miljømærkning er også en del af erhvervslivets grønne indsats. Derfor er erhvervssektoren i ministerrådet en oplagt samarbejdspartner angående Svanen. 


\section{ANBEFALING 8 \\ STØTTE LANDENE I AT OPTIMERE BRUGEN AF OFFENT- LIGE MIDLER TIL FREMME AF GRØN OMSTILLING}

Omstilling til lavemissionssamfund kræver øget finansiering af miljø- og klimavenlige innovationer. De offentlige finansielle støtteordninger, offentligt indkøb og brugen af offentlig finansiering af større infrastrukturprojekter udgør samlet set en strøm af midler med stort potentiale til at fremme udvikling, kommercialisering og implementering af grønne løsninger. Det nordiske miljø- og klimasamarbejde bør bidrage til en erfaringsudveksling og vidensopbygning mellem de nordiske lande om, hvordan disse instrumenter bedst kan anvendes til fremme af grøn omstilling.

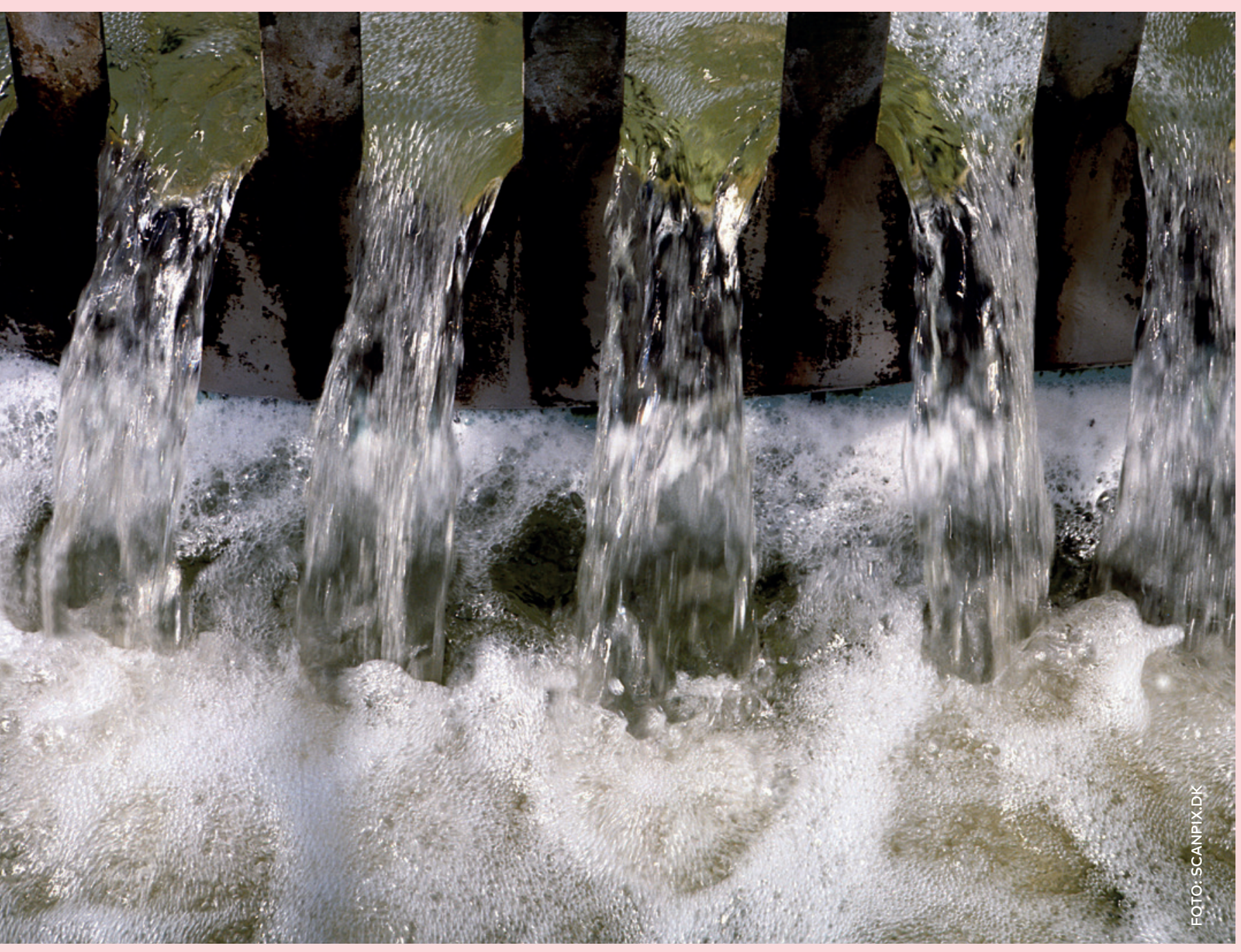


Det er blevet estimeret, at der er behov for yderligere 170 milliarder euro årligt i grønne løsninger alene i EU-området for at opfylde målene for 2030 i Paris-aftalen. Opfyldelsen af miljømål i 2030-agendaen kræver en endnu større finansieringsindsats. Der er behov for midler til udvikling, kommercialisering og implementering af større systemiske og infrastrukturmæssige ændringer såvel som mindre innovationer på stort set alle områder inden for økonomisk aktivitet. I de kommende år er det især vigtigt at få fart i kommercialiseringen af lovende og allerede testede løsninger til lavemissionssamfund.

I de nordiske lande har man forskellige offentlige ordninger til finansiel støtte såsom lån, tilskud og garantier til innovationer, både grønne og ikkegrønne. Der findes fonde, programmer og puljer, som både offentlige og private kan søge støtte fra. Finansiering gives typisk til udvikling, test og demonstration. Nogle finansieringsinstrumenter støtter også videre tiltag til markedsudvikling. Denne type af offentlig støtte er essentiel for udvikling og spredning af nye innovationer. Ovenikøbet kan offentlig finansiel støtte hjælpe til at tiltrække privat kapital til mere risikofyldte innovations- og kommercialiseringsprojekter.

Det anbefales konkret, at der initieres en nordisk erfaringsudveksling og vidensopbygning om instrumenter til finansiel støtte fra det offentlige. Formålet med erfaringsudvekslingen er at give landene en bedre forståelse for, hvordan disse instrumenter bedst kan anvendes til gavn for grøn omstilling. I denne sammenhæng kan det også være frugtbart at diskutere, om yderligere servicer såsom rådgivning og sparring i forbindelse med støttemidler kan give øget effekt af de anvendte midler. Herudover er det også vigtigt at drøfte den kombinerede effekt af forskellige ordninger såvel som at vurdere eventuelle behov for at gøre nogle af de andre eksisterende støtteinstrumenter grønnere. Baseret på denne viden kan de nationale mekanismer og ordninger til finansiel støtte optimeres for at fremme grøn omstilling.
Udover de ovennævnte støttemekanismer findes der andre måder, hvorpå de offentlige midler kan anvendes til fremme af grønne innovationer og løsninger. Offentligt indkøb og offentlige investeringer har stort potentiale i forhold til at stimulere efterspørgsel på miljøvenlige produkter, servicer og andre løsninger på systemniveau. Der anbefales derfor yderligere videns- og erfaringsdeling om, hvordan man i de nordiske lande har kunnet allokere offentlige midler til støtte for grøn omstilling via offentligt indkøb og offentlige investeringer. 


\section{ANBEFALING 9 \\ ORGANISERE ET NORDISK TOPMØDE OM UDVIKLING AF GRØNNE FINANSMARKEDER}

Der er stort behov for at omdirigere både private og offentlige kapitalinvesteringer til støtte af grøn omstilling. For at katalysere en grøn transition af finansmarkeder er EU-Kommissionen ved at formulere en række indsatser for et grønnere finansmarked. Som opfølgning på og udvikling af dette bør de nordiske miljø- og klimaministre organisere et nordisk topmøde, som samler nøgleaktører for udvikling af grønnere finansmarkeder i Norden.

\section{0}

Alfred Berg Kapitalförvaltning • CB Fonder • Handelsbanken Fonder - SEB Investment Management • Skandia Fonder • Swedbank Robur Fonder • Tundra Fonder
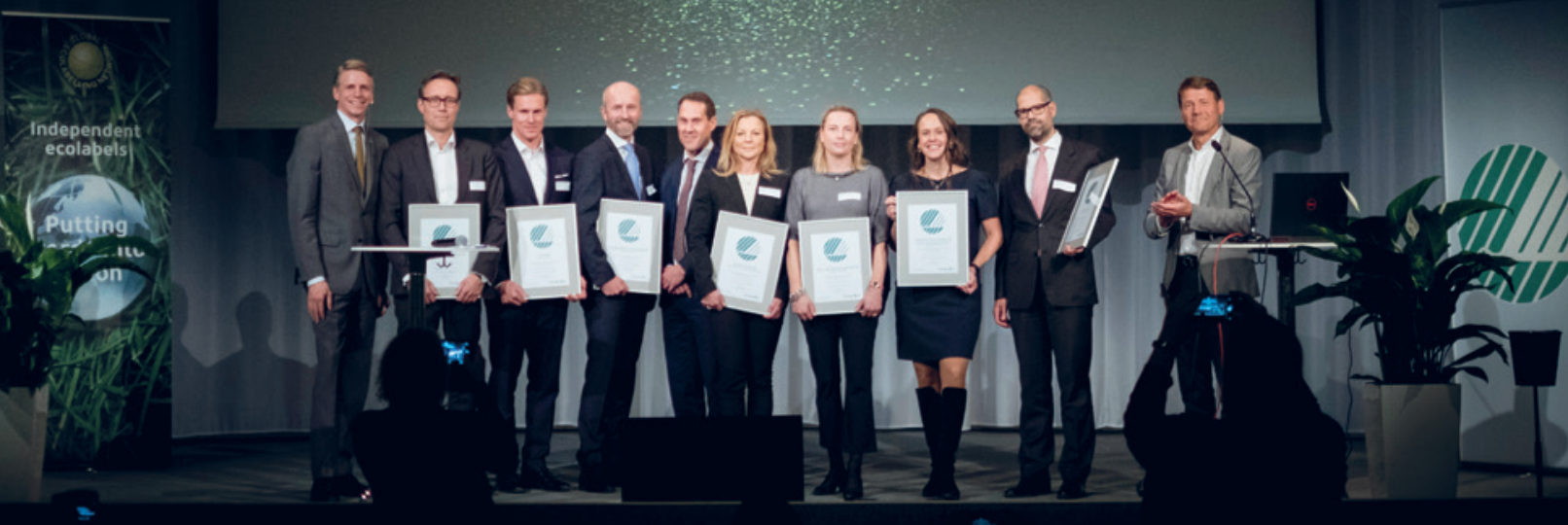

is 
Opfyldelsen af målsætningerne i både Parisaftalen om klima og de målsætninger i 2030-agendaen, som har tilknytning til miljø og klima, kræver en grundlæggende ændring i anvendelsen af finansielle ressourcer. De offentlige støttemidler, offentligt indkøb og offentlige satsninger inden for miljø- og klimavenlig infrastruktur er en begyndelse (anbefaling 8). Der hersker dog ingen tvivl om, at dette ikke er tilstrækkeligt: Privat kapital og kapital fra institutionelle investorer skal mobiliseres, hvis vi vil nå målet.

EU High-Level Expert Group on Sustainable Finance (HLEG) har netop offentliggjort sine anbefalinger for, hvordan et grønnere finanssystem kunne opbygges på EU-niveau. En af gruppens hovedkonklusioner er, at ændringer skal ske på mange forskellige områder i finansverden. HLEG understreger især behovet for udvikling af fælles definitioner og standarder for grønne investeringer og investeringsprodukter, transparente og sammenlignelige data om grønne investeringsmuligheder og risici relateret til miljø og klima. Derudover peger anbefalingerne på muligheder for bedre integration af bæredygtighedsaspekter i arbejdet i både finansielle institutioner og de finansielle tilsyn. Gruppen foreslår blandt andet også tiltag rettet mod banker, forsikringsselskaber, formuepleje og børser.

Anbefalingerne fra HLEG viser klart, at der er behov for både policy-tiltag og samarbejde med private finansieringsinstitutioner og -organisationer. EU's handleplan for bæredygtig finansiering, som forventes offentliggjort i marts 2018, kommer til at udstikke retningen for arbejdet på EU-niveau. Dette arbejde bør støttes og komplementeres med tiltag på regionalt og nationalt plan. Det anbefales derfor, at de nordiske miljø- og klimaministre initierer en dialog med finansministre og nøgleaktører på finansområdet, såsom de store institutionelle investorer, brancheorganisationer fra den finansielle sektor og Nordisk Investeringsbank, for at definere og undersøge muligheder for nordiske indsatser. Disse drøftelser er også vigtige for at støtte op omkring og inspirere til udvikling i landene. Helt konkret kan disse drøftelser tage form af et officielt nordisk topmøde eller en åben og eksplorativ dialog på topniveau. 


\section{ANBEFALING 10 \\ UDVIKLE EN PLAN FOR NORDISK SAMARBEJDE I INTERNATIONALE FORA}

De kommende tre år er afgørende for internationale miljøpolitiske forhandlingsprocesser inden for klima-, biodiversitets- og kemikalieområdet. De nordiske miljø- og klimaministre bør udvikle en plan for, hvor i disse processer der bør gennemføres strategiske nordiske indsatser. Planen må følges op med midler til vidensopbygning, spredning af viden og best practices samt fælles forhandlingsindsatser både i det officielle og vofficielle nordiske miljø- og klimasamarbejde.

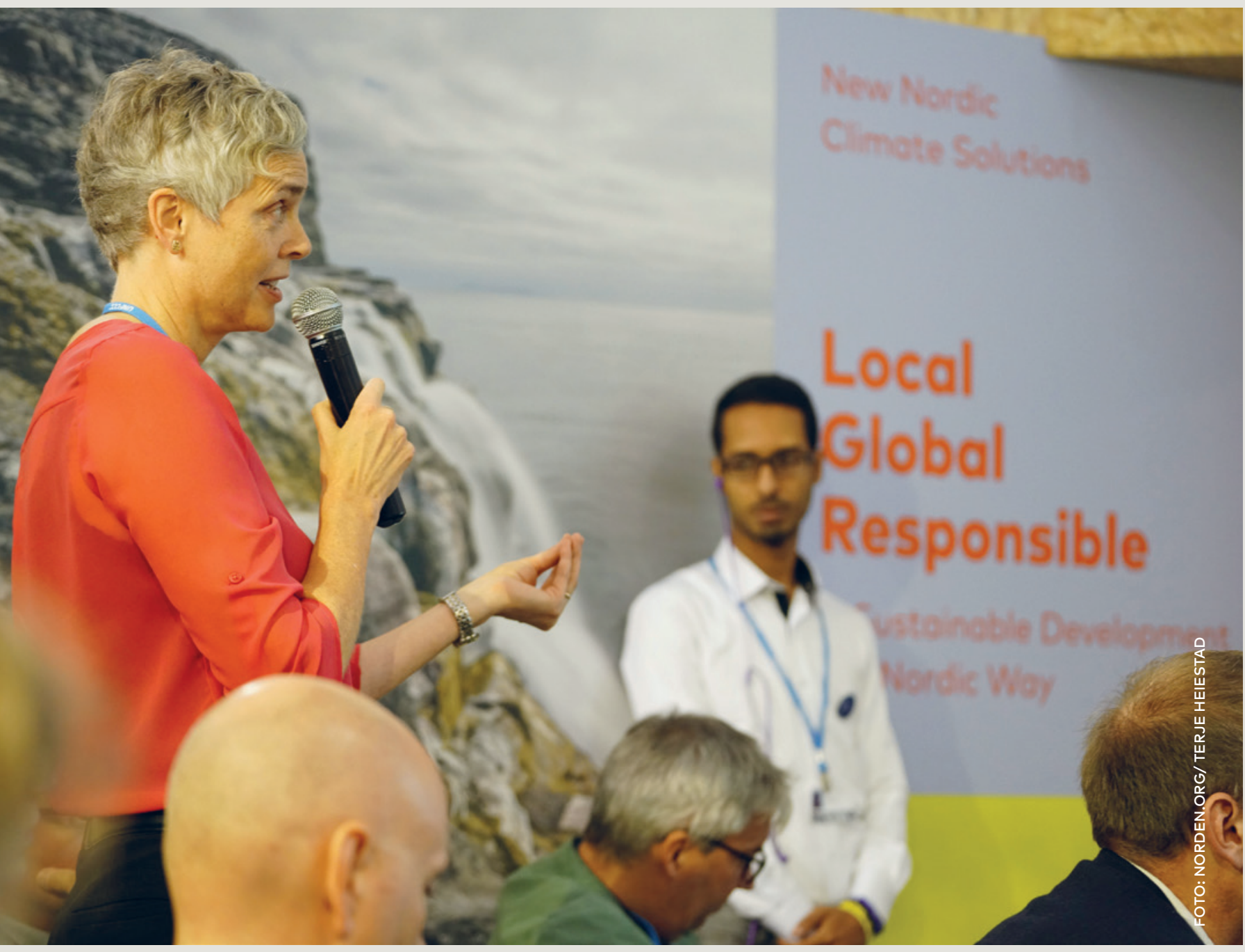


De nordiske lande nyder stor respekt internationalt. Dette bygger på det seriøse miljø- og klimaarbejde, der bliver gennemført i de nordiske lande. Herudover spiller de nordiske lande en aktiv, dialog- og vidensbaseret rolle i internationale sammenhænge. Det betyder samlet set, at de nordiske lande har mere politisk "soft power", end befolkningstallene umiddelbart tilsiger.

Det nordiske samarbejde har været med til at opbygge det gode billede og den troværdighed, som de nordiske lande nyder godt af i internationale sammenhænge. Nordiske midler er blevet brugt til at generere viden om miljøet og klimaet. De nordiske lande har i fællesskab fremmet specifikke spørgsmål i forhandlingerne gennem fælles deklarationer og gennem gensidigt at støtte hinandens forslag. I forbindelse med klimaforhandlingerne har de nordiske forhandlere et godt samarbejde i den nordiske arbejdsgruppe for klimaforhandlingerne (NOAK). De eksisterende uofficielle nordiske netværk af forhandlere uden for det officielle nordiske miljø-og klimasamarbejde vidner også om styrken i at samarbejde nordisk.

De kommende år bliver præget af vigtige internationale forhandlingsprocesser angående klima, kemikalier og biodiversitet. Globalt fortsat stigende $\mathrm{CO}_{2}$-emissioner gør ikke opfyldelsen af Parisaftalen nem. Den internationale strategi for international kemikaliehåndtering (SAICM) udløber i 2020, og drøftelserne om en mulig international platform for kemikalier og affald er påbegyndt. På biodiversitetsområdet har man initieret forberedelserne til processen frem mod et nyt globalt post 2020-rammeværk for biodiversitet i FN-regi.

De nordiske lande kan nå længere ved at samarbejde i internationale fora. Selvom internationale forhandlinger ofte er præget af udviklinger, som er vanskelige at forudse, handler forhandlingerne også om lange strategiske stræk inden for velkendte problemstillinger. Derfor bør de nordiske miljø- og klimaministre udvikle en plan for, hvordan strategiske nordiske indsatser anvendes i disse processer for at opnå de resultater, som landene sammen ønsker at opnå i de kommende år. Planen bør være et strategisk og levende værktøj, som muliggør systematisk brug af vidensopbygning samt spredning af viden og best practices som en del af fælles indsatser ved kommende forhandlinger. Planen bør udarbejdes i samspil med de relevante officielle nordiske arbejdsgrupper såvel som med de uofficielle nordiske netværk. Denne forankring muliggør en optimeret brug af midler og andre muligheder, som samarbejdet på ministerniveau tilbyder. 


\section{ANBEFALING 11 \\ UDARBEJDE EN NORDISK HANDLINGSPLAN FOR KLIMARESILIENS FOR ØKOSYSTEMER OG NATURENS MANGFOLDIGHED}

Klimaforandringer øger presset på vores økosystemer og deres grundsten, biodiversiteten. Det udfordrer de tjenester, som økosystemer leverer til os i form af fx føde, ren luft og vand. Nu og i fremtiden er økosystemernes klimaresiliens derfor afgørende for vores livskvalitet og økonomi. De nordiske lande bør etablere en nordisk handlingsplan for videns- og kapacitetsopbygning inden for øget klimaresiliens i naturen. Nordisk samarbejde kræves også for at sikre dyrs og planters mulighed for tilpasning til de nye klimaforhold på tværs af nordiske landegrænser.

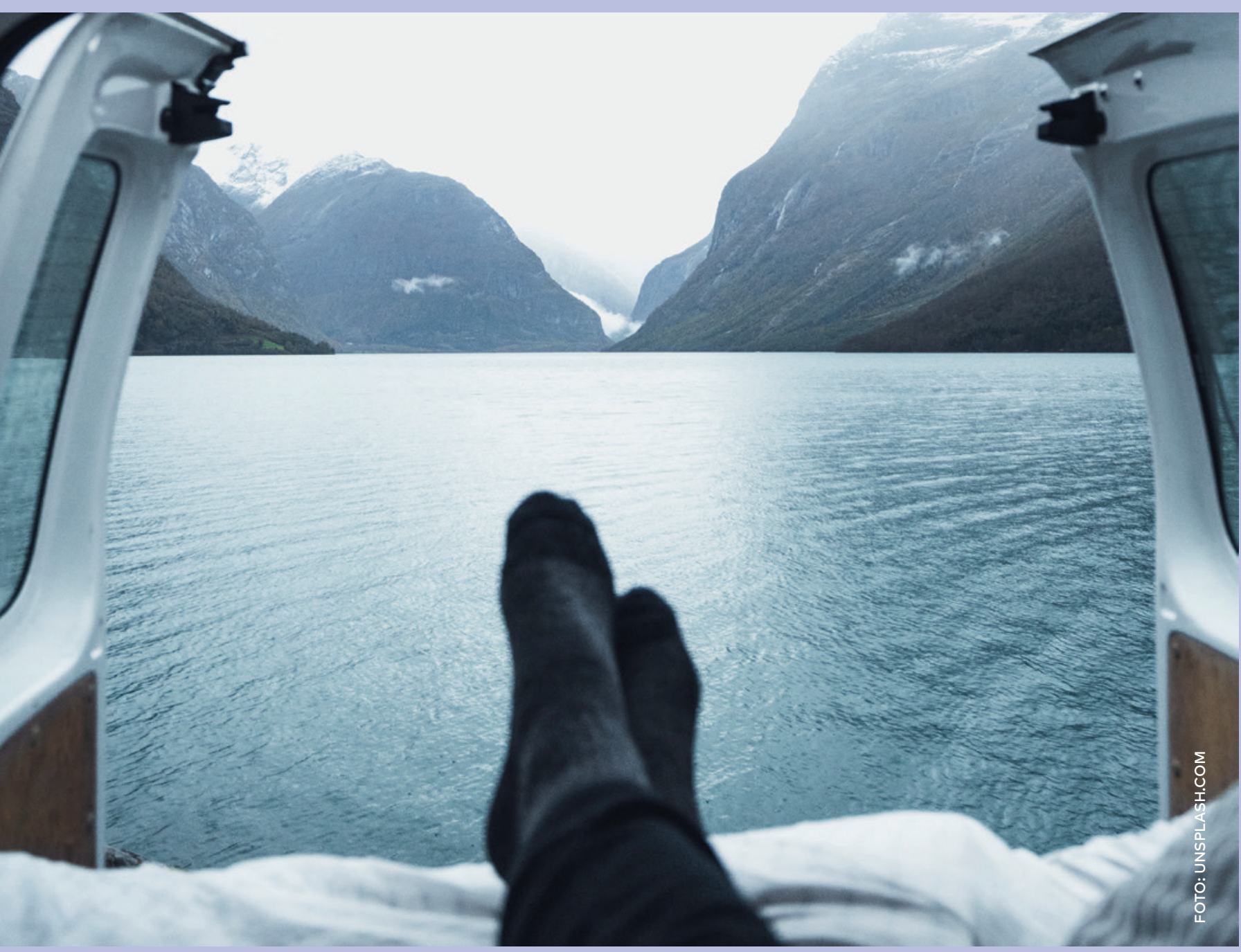


Vi er dybt afhængige af økosystemtjenester såsom rent vand og ren luft, føde, bestøvning og klimaregulering. Trods dette lægger de menneskelige og økonomiske aktiviteter, såsom landbrug, skovbrug, fiskeri, byudvikling og udbygning af infrastruktur, et stort pres på økosystemerne og deres modstandskraft. Økosystemer fragmenteres og ødelægges, hvilket leder til, at livsvilkår for forskellige arter forringes, og naturens mangfoldighed reduceres. Eftersom biodiversitet er afgørende for økosystemernes evne til at levere tjenester og for deres resiliens, bliver disse derigennem yderligere svækket.

Klimaforandringer forstærker presset på vores økosystemer yderligere. Tempoet $\mathrm{i}$ temperaturstigning og ændringer i klimaet vil overstige den hastighed, hvormed arterne kan nå at tilpasse eller flytte sig til andre udbredelsesområder. Derved øges risikoen for, at arterne svækkes eller dør, betydeligt. Nedgang i biodiversitet påvirker de enkelte økosystemers evne til at levere økosystemtjenester. Når naturens mangfoldighed i sin helhed reduceres, falder økosystemernes totale ydeevne også.

Sunde og robuste økosystemer står stærkere mod klimaforandringers påvirkning. Resiliente økosystemer har også lettere ved at restituere og tilpasse sig ændrede livsvilkår. Den bedste strategi for at øge og bevare resiliensen er at sørge for en tilstrækkelig bred vifte af arter og en tilstrækkelig mængde af habitater. Dette gøres dels ved at forstærke de allerede svækkede økosystemer og dels ved at minimere presset fra de øvrige stressfaktorer på de robuste og sunde økosystemer. Udover dette er det vigtigt at sikre tilknytning mellem habitater, således at de grønne og blå korridorer muliggør en naturlig migration.

Arbejdet med klimatilpasning er allerede påbegyndt i alle de nordiske lande. De nordiske lande har også iværksat forskningsinitiativer for at se på, hvor og hvilke naturtyper og økosystemer der vil blive mest påvirket af klimaforandringer. Samtidig er de nordiske lande inden for rammen af det nor- diske samarbejde ved at gøre status på de nordiske økosystemer og økosystemtjenester (Nordisk IBPES). Det er et godt tidspunkt at lære af hinanden og sammenligne de nationale indsatser for eksempel inden for klimaintegreret forvaltning af natur, den fysiske planlægning af arealforbrug og indsatsen inden for sektorer, der påvirker naturens evner til at restituere og udvikle sig. Samarbejdet bør derfor omfatte lovgivning, virkemidler, støtteordninger og lokale aktørers rolle i arbejdet med klimaresiliens. Konkrete metoder til bedre sammenhæng, øget restitutionsevne, genopretning og dynamisk udvikling af økosystemer er ligeledes essentielle som fokus for samarbejde for at bevare og forbedre status på økosystemer i Norden som region. Ydermere er det muligt at identificere fælles problemområder i den nordiske natur, såsom de arktiske områder og kystnatur, samt at sikre spredningskorridorer i Norden. Gennem systematisk nordisk samarbejde og arbejdsdeling omkring videns- og kapacitetsopbygning for øget klimaresiliens kan de nordiske lande nå langt med deres samlede midler. 


\section{ANBEFALING 12 \\ VIDEREUDVIKLE FORMER FOR NORDISK SAMARBEJDE, SOM ØGER NORDISK NYTTE}

Det nordiske miljø- og klimasamarbejde er velfungerende og velforankret i landene. Samarbejdsformerne kan dog stadig udvikles med henblik på at opnå større effekt og fordele for landene. Med strategiske spydspidsinitiativer, øget arbejdsdeling mellem landene og koordination af nationale midler og arbejdsindsatser kan landene opnå endnu større miljøeffekt. Ved at et land agerer vært for et specifikt initiativ forstærkes tilknytningen til den nationale policy-kontekst og ekspertise yderligere.

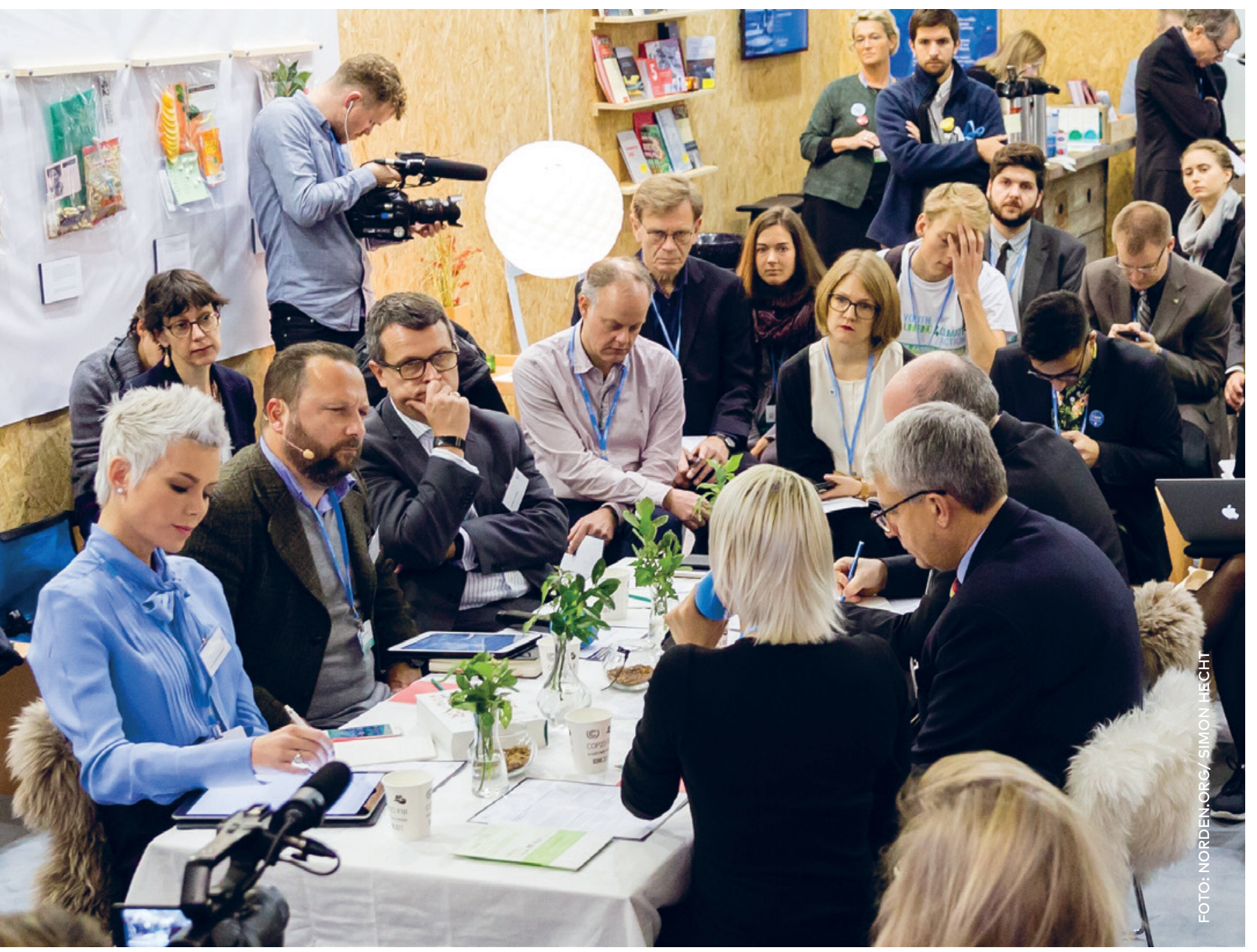


Nordisk miljø-og klimasamarbejde omfatter et stort spektrum af relevante temaer. Det er velforankret i de nordiske lande. National deltagelse i arbejdsgrupper engagerer et stort nordisk netværk og sørger for en direkte kobling til de nationale agendaer. Samarbejdet er samtidig stærkt defineret af bredden af det nordiske netværk, hvilket giver en risiko for fragmentering. En anden konsekvens af, at arbejdet stort set udelukkende gennemføres i faste arbejdsgrupper, er, at opgaver med temaer uden for arbejdsgruppernes kompetenceområder bliver udfordrende. Det nuværende nordiske miljøog klimasamarbejde kan derfor med fordel komplementeres af tre forskellige slags arbejdsformer, som bliver præsenteret i det følgende.

For det første kan store spydspidssatsninger anvendes i større omfang i det nordiske miljø- og klimasamarbejde for at fremme områder med strategisk høj prioritet. For at facilitere strategisk prioritering i sektoren anbefales det, at landene med hjælp fra deres nationale topembedsmænd og myndighedspersoner definerer strategiske indsatser for to-treårige programlignende perioder. Dette kan gøres gennem $\mathrm{fx}$ at invitere chefer for specifikke nationale myndigheder til dialogmøder. Ved siden af disse spydspidsinitiativer skal der stadigvæk findes plads til initiativer af mere ad hoc karakter samt netværksarbejde i arbejdsgrupperne.

For det andet har arbejdsgruppestrukturen sine begrænsninger ift. nordiske initiativer, der kræver kompetencer, som medlemmerne i arbejdsgrupperne ikke er i besiddelse af. I forhold til denne type initiativer kunne man overveje at placere det udviklende og koordinerende ansvar og tilhørende midler hos én national myndighed. Fordelen ved dette ville være, at man herved kunne koble de relevante eksperter direkte til projektledelsen, og at man kunne sikre adgang til den samlede kompetencepulje i værtsinstitutionen. Værtslandet kunne vælges baseret på formandskabsturnus eller interesser og muligheder. I den nordiske miljøsektor har man tidligere brugt lignende organiseringsmetoder for eksempel i plast- og tekstilarbejdet.
For det tredje kan effekten af det nordiske samarbejde blive større, hvis medlemslandene betragter de nordiske midler som katalysator for videre samarbejde og det nordiske samarbejde som platform for koordinering af og mellem nationale indsatser. det nordiske kemikaliesamarbejde har man i nogle tilfælde koordineret landenes nationale indsatser i forhold til kemikalievurdering i EU. Resultatet har været et bredere bidrag med større gennemslagskraft. I nogle tilfælde har vi også set, at enkelte lande supplerer de nordiske midler med nationale midler for at skabe et projekt eller initiativ af større omfang. I princippet kunne nationale midler fra alle nordiske lande - eller dem, som er interesserede lægges sammen eller koordineres for at give mere styrke til de specifikt afgrænsede arbejdsområder, som landene har fælles interesse for. Koordinering af de nationale indsatser og af nationale midler er især nærliggende for vidensopbygning og kommunikation. 
Nordisk Ministerråd

Nordens Hus

Ved Stranden 18

1061 København K

www.norden.org

\section{DE NORDISKE LANDE I DEN GRøNNE OMSTILLING - MERE END NABOER}

De nordiske lande har gennem flere årtier samarbejdet om miljø- og naturbeskyttelse i Norden såvel som internationalt. Denne rapport fremlægger anbefalingerne fra en ekstern strategisk undersøgelse af det fremtidige potentiale for det officielle nordiske miljø- og klimasamarbejde inden for rammerne af Nordisk Ministerråd for Miljø og Klima. Anbefalingerne peger på muligheder for, hvordan samarbejdet kan udvikle sig som en endnu mere relevant og konkret drivkraft for den grønne omstilling. Anbefalinger knytter sig til fem overordnede områder, hvor det nordiske miljø- og klimasamarbejde bør gøre sig tydeligt gældende: konkrete løsninger til grøn omstilling, mobilisering af nøgleaktører, finansiering af grøn omstilling, internationalt samarbejde og tilpasning til de klimamæssige ændringer.

Denne rapport er en del af en serie af strategiske og fremadrettede unders $\varnothing$ gelser i Nordisk Ministerråd. De tidligere undersøgelser, såkaldte strategiske gennemlysninger, omhandler arbejdsliv, sundhed og energi. Gennemlysningerne er tilknyttet reformarbejdet Nyt Norden i ministerrådet. 